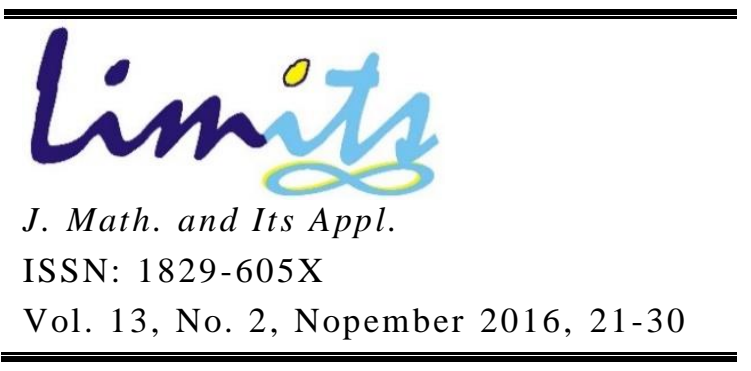

\title{
PENDEKATAN FUNGSI POLYNOMIAL DARI BENDA PUTAR DENGAN METODE ELIMINASI GAUSS JORDAN
}

\author{
Ulul Azmi ${ }^{1}$, Rita Yuliastuti ${ }^{2}$, Kresna Oktafianto ${ }^{3}$ \\ ${ }_{1,3}$ Prodi Matematika FMIPA, Universitas PGRI Ronggolawe \\ ${ }^{2}$ Prodi Pendidikan Matematika FKIP, Universitas PGRI Ronggolawe \\ 1alfa2aero@gmail.com, ${ }^{2}$ riitahabibi@gmail.com, ${ }^{3}$ k_oktafianto@yahoo.com
}

\begin{abstract}
In calculus, integral operation is usually used to calculate a wide or volume of an object. But in reality there is a lot of object that the function is still unknown while in integral we need to it to be calculated. In this paper we proposed an approach to get the mathematic function of an object based on its shape. Actually with a whole data from that object we can use elimination Gauss Jordan to get a function, but that function is uncertainly able to generate the desired graph that similar to the object. A graph from non-linier function usually undergoing some change at some point, which is at extreme point and at turn point. With those point as a new limitation point we can get some new function that generate different or similar graph from each other. From those graph we compare them with the object shape and analyzing them to decide which one is the most approaching the object shape. In this paper we get the conclusion that in order to get the desired graph we need to test function from all three type of data then compare them to the real object shape.
\end{abstract}

Keywords: approach, function, gauss jordan, polynomial.

\section{Pendahuluan}

Integral merupakan cabang dari kalkulus yang sering digunakan dalam menghitung luas dan volume dari suatu obyek. Tetapi realitanya banyak obyek tidak diketahui fungsi matematisnya yang sangat dibutuhkan dalam operasi integral, misalnya pada benda putar yang selimutnya tidak rata. Data yang dapat diketahui dari benda tersebut hanyalah tinggi dan jari-jarinya [1].

Metode eliminasi Gauss Jordan [2] dapat digunakan untuk membentuk sebuah fungsi dari data tersebut. Tetapi fungsi tersebut belum tentu dapat menghasilkan grafik yang mirip atau sama dengan benda putar yang diteliti. Sehingga untuk mendapat fungsi benda yang grafiknnya sesuai dengan benda putar yang diteliti perlu terlebih dahulu mengamati karakter bentuk dari benda tersebut. Fungsi non-linear biasanya mengalami dua jenis perubahan, yaitu 
perubahan arah pada titik ekstrem dan perubahan kecekungan pada titik belok.

Dengan menggunakan titik-titik tersebut sebagai titik batas yang baru maka dapat dibentuk fungsi lain dengan menggunakan metode eliminasi gauss jordan. Dari semua fungsi yang didapatakan menghasilkan grafik fungsi yang saling mirip ataupun sangat berbeda satu dengan yang lain. Kemudian dengan membandingkan grafik-grafik tersebut terhadap bentuk benda putar yang diteliti maka akan didapat susunan grafik yang paling mendekati bentuk benda putar yang diteliti.

\section{Metode Penelitian}

Sekumpulan data yang dimisalkan berasal dari satu fungsi yang sama dapat dituliskan dalam sebagai suatu sistem persamaan linear, yaitu dengan mensubstitusikan nilai " $x$ " dan " $y$ " yang diketahui pada data kedalam persamaan polynomial.

$$
\begin{aligned}
& \qquad f(x)=y \\
& f(x)=a_{0}+a_{1}(x)+a_{2}(x)^{2}+\cdots+ \\
& \quad \quad \text { a variable } a_{n-1}(x)^{n-1}=y \\
& A, y \quad \text { konstanta } \\
& N \quad \text { : banyaknya data }
\end{aligned}
$$

Sehingga dengan $\mathrm{n}+1$ data didapatkan system persamaan linear [3] seperti berikut:

$$
\begin{aligned}
& f\left(x_{0}\right)=a_{0}+a_{1}\left(x_{0}\right)+\cdots+a_{n}\left(x_{0}^{n}\right) \\
& =y_{0} \\
& f\left(x_{1}\right)=a_{0}+a_{1}\left(x_{1}\right)+\cdots+a_{n}\left(x_{1}^{n}\right) \\
& =y_{1} \\
& f\left(x_{2}\right)=a_{0}+a_{1}\left(x_{2}\right)+\cdots+a_{n}\left(x_{2}^{n}\right) \\
& =y_{2} \\
& \vdots+\vdots+\vdots+\cdots=\vdots \\
& f\left(x_{n}\right)=a_{0}+a_{1}\left(x_{n}\right)+\cdots+a_{n}\left(x_{n}^{n}\right) \\
& =y_{n}
\end{aligned}
$$

Sistem persamaan linear pada persamaan 3 dapat ditulis dalam bentuk matrik $X A=Y$.

$$
\left[\begin{array}{ccccc}
1 & x_{0} & x_{0}^{2} & \cdots & x_{0}^{n} \\
1 & x_{1} & x_{1}^{2} & \cdots & x_{1}^{n} \\
1 & x_{2} & x_{2}^{2} & \cdots & x_{2}^{n} \\
\vdots & \vdots & \vdots & \ddots & \vdots \\
1 & x_{n} & x_{n}^{2} & \cdots & x_{n}^{n}
\end{array}\right]\left[\begin{array}{c}
a_{0} \\
a_{1} \\
a_{2} \\
\vdots \\
a_{n}
\end{array}\right]=\left[\begin{array}{c}
y_{0} \\
y_{1} \\
y_{2} \\
\vdots \\
y_{n}
\end{array}\right]
$$

Dari persamaan 4 matrik $X A=Y$ dapat diselesaikan dengan metode eliminasi Gauss Jordan sehingga didapatkan nilai dari variabel $a_{0}, a_{1}, a_{2}, \ldots, a_{n}$ adalah $k_{0}, k_{1}, k_{2}, \ldots, k_{n}$. Sehingga dengan mensubstitusikan 
kembali nilai $a_{0}, a_{1}, a_{2}, \ldots, a_{n}$ tersebut kedalam persamaan 2 akan didapatkan suatu fungsi polynomial dengan variable $x$ seperti berikut.

$$
f(x)=k_{0}+k_{1} x+k_{2} x^{2}+\cdots+k_{n} x^{n}
$$

\section{Pembahasan}

Dalam penelitian ini diambil sampel data dari dua buah vas kayu berikut.

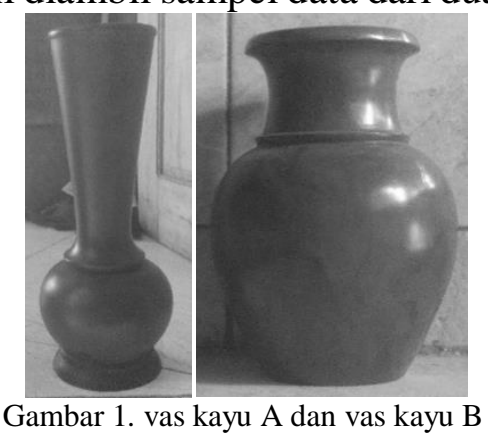

Pada gambar 1 terlihat ada beberapa titik batas pada kedua vas, sehingga tidak mungkin terbentuk fungsi dengan seluruh data pada vas. Jadi data yang didapat dibagi menjadi beberapa bagian mengikuti titik batas dari vas. Pembagian batas-batas pada vas kayu A ditunjukan pada gambar 2.

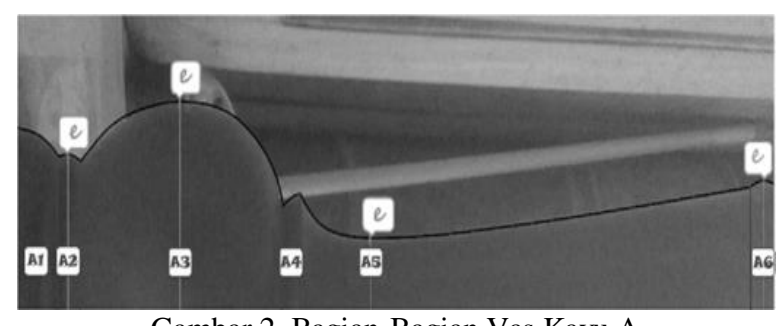

Gambar 2. Bagian-Bagian Vas Kayu A

Sedangkan pembagian batas-batas pada vas kayu B ditunjukan pada gambar 3.

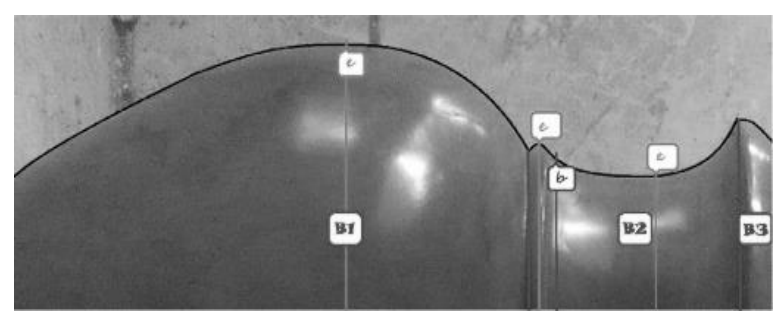

Gambar 3. Bagian-Bagian Vas Kayu B

Dari gambar 2 didapat data ditiap bagian vas A seperti yang ditunjukan pada tabel 1.

Tabel 1. Data vas kayuA $(\mathrm{cm})$

\begin{tabular}{|c|c|c|c|c|c|c|c|}
\hline \multirow{2}{*}{\multicolumn{2}{|c|}{ Daerah }} & \multicolumn{2}{|c|}{ Koordinat } & \multirow{2}{*}{\multicolumn{2}{|c|}{ Daerah }} & \multicolumn{2}{|c|}{ Koordinat } \\
\hline & & \multirow{2}{*}{$\begin{array}{l}\mathbf{X} \\
\mathbf{0}\end{array}$} & \multirow{2}{*}{$\frac{y}{6.78}$} & & & \multirow{2}{*}{$\frac{x}{13.78}$} & \multirow{2}{*}{$\frac{y}{4.36}$} \\
\hline \multirow{3}{*}{ « } & \multirow{3}{*}{ 飞 } & & & \multirow{3}{*}{2} & \multirow{3}{*}{ ֶ̃ } & & \\
\hline & & 0.5 & 6.7 & & & 14 & 4 \\
\hline & & 1 & 6.52 & & & 15 & 3.09 \\
\hline
\end{tabular}




\begin{tabular}{|c|c|c|c|c|c|c|c|}
\hline & & 1.5 & 6.21 & & & 16 & 2.79 \\
\hline & & $?$ & 572 & & & 17 & 2.7 \\
\hline \multirow{5}{*}{2} & \multirow{2}{*}{$\underset{\mathbb{Z}}{\mathbb{Z}}$} & 2.25 & 5.79 & & \multirow{8}{*}{\begin{tabular}{l}
$\mathscr{U}$ \\
\multirow{2}{*}{}
\end{tabular}} & 17.6 & 2.68 \\
\hline & & & & & & 19 & 2.72 \\
\hline & \multirow{3}{*}{$\underset{\mathcal{U}}{\mathrm{d}}$} & 2.45 & 5.81 & & & 22 & 2.94 \\
\hline & & 2.8 & 5.71 & & & 25 & 3.23 \\
\hline & & 305 & 553 & & & 28 & 3.57 \\
\hline \multirow{11}{*}{2} & \multirow{6}{*}{ 仓̃ } & $\mathbf{5 . 0 5}$ & 5.53 & & & 31 & 3.96 \\
\hline & & 4 & 6.41 & & & 34 & 4.35 \\
\hline & & 5 & 7.1 & & & 358 & 4,58 \\
\hline & & 6 & 7.48 & & \multirow{3}{*}{ ֻ } & 35.0 & \\
\hline & & 7 & 7.69 & & & 36 & 4.71 \\
\hline & & 8 & 777 & & & 36.15 & 4.78 \\
\hline & \multirow{5}{*}{ 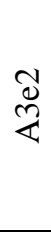 } & 9 & 7.7 & 远 & \multirow{4}{*}{ 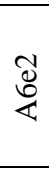 } & 36.45 & 4.82 \\
\hline & & 10 & 7.47 & & & 36.7 & 4.78 \\
\hline & & 11 & 6.93 & & & 36.9 & 4.71 \\
\hline & & 12 & 5.96 & & & 37 & 4.66 \\
\hline & & 12.9 & 3.85 & & & & \\
\hline \multirow{3}{*}{$\underset{\&}{ \pm}$} & \multirow{3}{*}{$\underset{\&}{*}$} & 13.25 & 4.11 & & & & \\
\hline & & 13.5 & 4.25 & & & & \\
\hline & & 13.78 & 4.36 & & & & \\
\hline
\end{tabular}

Keterangan:

An : bagian vas kayu A ke- $n$

em : bagian ke- $n$ yang dibatasi titik ekstrem

$\mathrm{n} \quad=1,2,3,4,5,6$

$\mathrm{m} \quad=1,2$

$\begin{array}{ll}\square . . . .1 & : \text { titik batas } \\ : & \text { : titik ekstrem }\end{array}$

Selanjutnya dari gambar 3 didapat data ditiap bagian vas B seperti yang ditunjukan pada tabel 2.

Tabel 2. Data vas kayu B (cm)

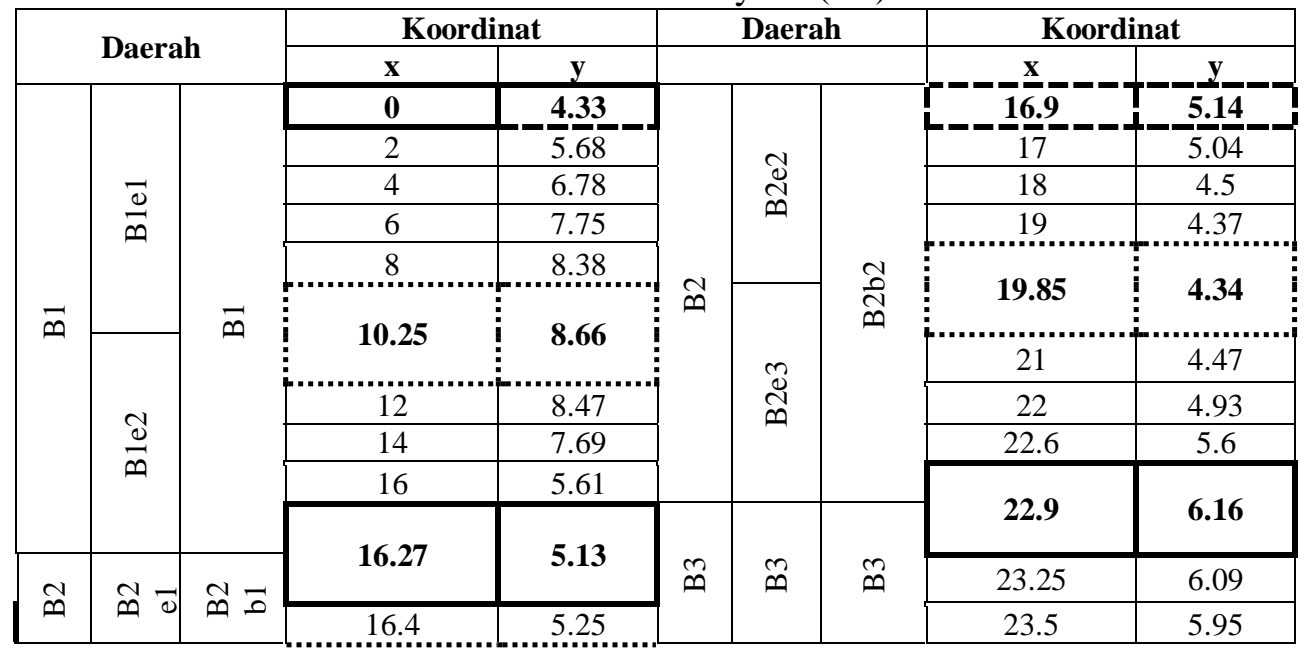




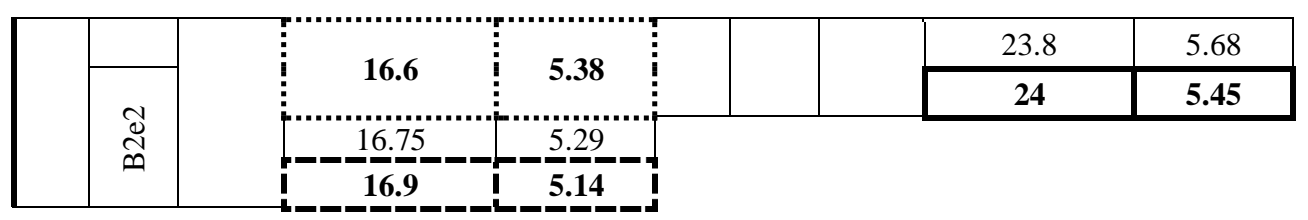

Keterangan:

Bn : bagian vas kayu B ke- $n$

em : bagianke- $n$ yang dibatasi titik ekstrem

bm : bagianke- $n$ yang dibatasi titik belok

$\mathrm{n} \quad=1,2,3$

$\mathrm{m} \quad=1,2,3$

\begin{tabular}{|l|l}
\hline$\ldots . . .$. & : titik batas \\
\hdashline..- & : titik ekstrem \\
\hdashline & : titik belok
\end{tabular}

Berikutnya akan dihitung dan didapatkan fungsi-fungsi dari tiap bagian dengan menggunakan metode eliminasi gauss jordan.

Pada bagian A1 tidak memiliki titik ekstrem maupun titik belok sehingga hanya terbentuk satu fungsi dengan semua data A1.

Tabel 3. Data Bagian A1
\begin{tabular}{|c|c|c|}
\hline \multirow{2}{*}{ Daerah } & \multicolumn{2}{|c|}{ Koordinat } \\
\cline { 2 - 3 } & $\mathbf{x}$ & $\mathbf{y}$ \\
\hline \multirow{5}{*}{ A1 } & 0 & 6.78 \\
\cline { 2 - 3 } & 0.5 & 6.7 \\
\cline { 2 - 3 } & 1 & 6.52 \\
\cline { 2 - 3 } & 1.5 & 6.21 \\
\cline { 2 - 3 } & 2 & 5.72 \\
\hline
\end{tabular}

Dengan mensubstitusikan data pada tabel 3 ke persamaan 2 akan didapat suatu system persamaan linear seperti berikut.

$$
\begin{array}{ll}
f(0)=a_{0}+a_{1}(0)+a_{2}\left(0^{2}\right)+a_{3}\left(0^{3}\right)+a_{4}\left(0^{4}\right) & =6.78 \\
f\left(0.5=a_{0}+a_{1}(0.5)+a_{2}\left(0.5^{2}\right)+a_{3}\left(0.5^{3}\right)+a_{4}\left(0.5^{4}\right)\right. & =6.7 \\
f(1)=a_{0}+a_{1}(1)+a_{2}\left(1^{2}\right)+a_{3}\left(1^{3}\right)+a_{4}\left(1^{4}\right) & =6.52 \\
f\left(1.5=a_{0}+a_{1}(1.5)+a_{2}\left(1.5^{2}\right)+a_{3}\left(1.5^{3}\right)+a_{4}\left(1.5^{4}\right)\right. & =6.21 \\
f(2)=a_{0}+a_{1}(2)+a_{2}\left(2^{2}\right)+a_{3}\left(2^{3}\right)+a_{4}\left(2^{4}\right) & =5.72
\end{array}
$$

Sistem persamaan linear di atas ditulis dalam bentuk matrik ekstensi untuk nantinya diselesaikan dengan metode eliminasi gauss jordan.

$$
\left[\begin{array}{cccccc}
1 & 0 & 0 & 0 & 0 & \frac{678}{100} \\
1 & \frac{1}{2} & \frac{1}{4} & \frac{1}{8} & \frac{1}{16} & \frac{67}{10} \\
1 & 1 & 1 & 1 & 1 & \frac{652}{100} \\
1 & \frac{3}{2} & \frac{9}{4} & \frac{27}{8} & \frac{81}{16} & \frac{621}{100} \\
1 & 2 & 4 & 8 & 16 & \frac{572}{100}
\end{array}\right]
$$


Eliminasi Gauss Jordan memanfaatkan operasi baris elementer untuk mengubah matrik menjadi matrik identitas

$$
\left[\begin{array}{cccccc}
1 & 0 & 0 & 0 & 0 & \frac{678}{100} \\
0 & 1 & 0 & 0 & 0 & -\frac{7}{100} \\
0 & 0 & 1 & 0 & 0 & -\frac{53}{300} \\
0 & 0 & 0 & 1 & 0 & 0 \\
0 & 0 & 0 & 0 & 1 & -\frac{1}{75}
\end{array}\right]
$$
adalah

Sehingga dari matrik di atas dapat diketahui nilai dari $a_{0}, a_{1}, a_{2}, a_{3}, a_{4}$ $a_{0}=\frac{678}{100}, a_{1}=-\frac{7}{100}, a_{2}=-\frac{53}{100}, a_{3}=0, a_{4}=-\frac{1}{75}$

Substitusikan kembali nilai $a_{0}, a_{1}, a_{2}, a_{3}, a_{4}$ ke persamaan 2 maka didapat fungsi dan grafik A1 yang dibatasi di titik 0 samapai 2 adalah.

$$
f_{A 1}(x)=\frac{678}{100}-\frac{7}{100} x-\frac{53}{300} x^{2}+0-\frac{1}{75} x^{4}
$$

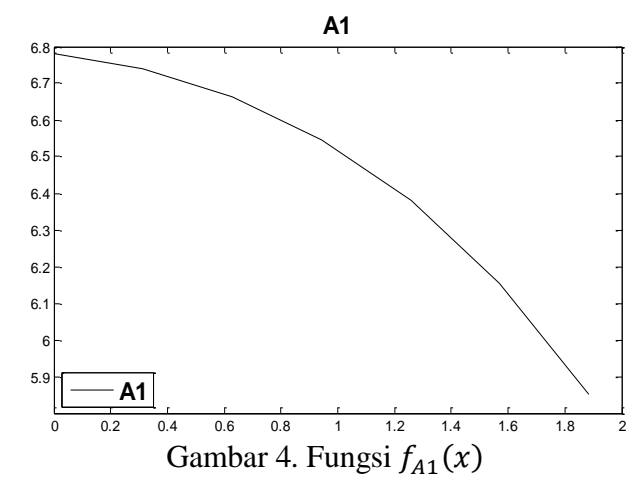

Pada bagian A2 ada dua tipe data, yaitu data seluruh bagian dan data yang dibatasi titik ekstrem. Sehingga terbentuk dua susunan fungsi dengan grafik.
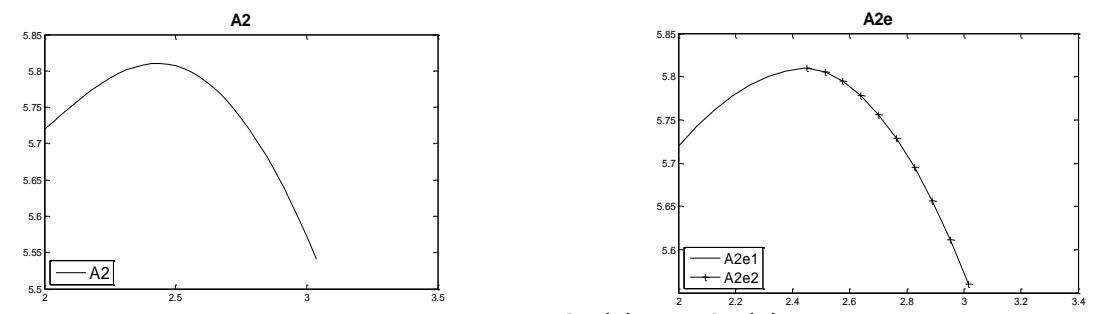

Gambar 5. Fungsi $f_{A 2}(x)$ dan $f_{A 2}^{22}(x)$

Pada bagian A3 ada dua tipe data, sehingga terbentuk dua susunan fungsi dengan grafik. 


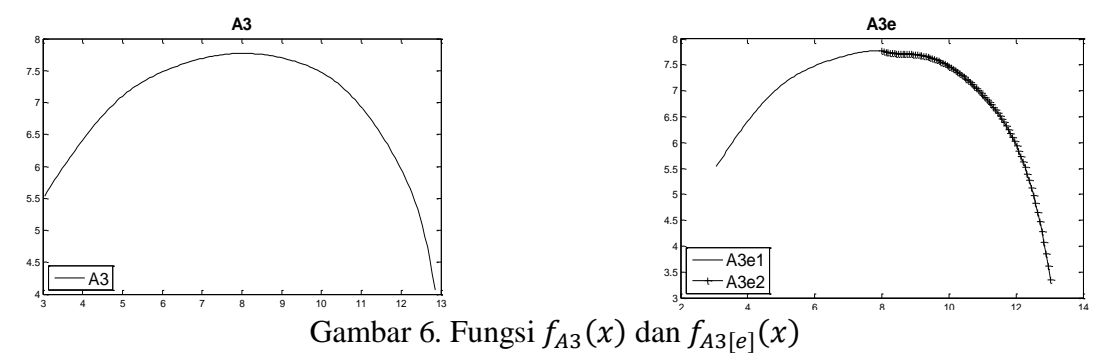

Bagian A4 hanya memiliki satu fungsi seperti pada A1.

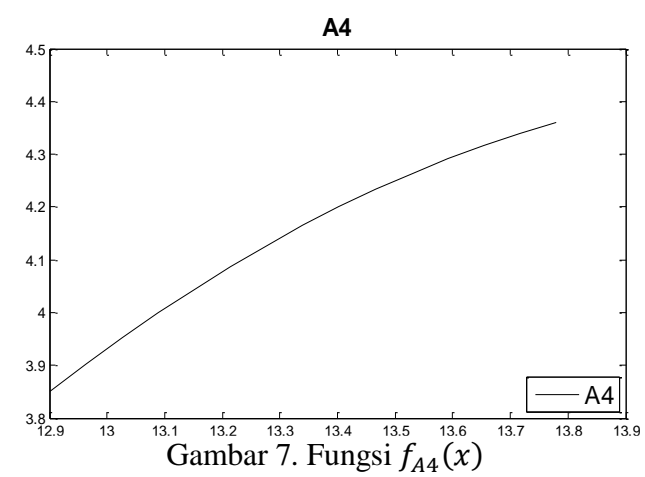

Pada bagian A5 ada dua tipe data, sehingga terbentuk dua susunan fungsi dengan grafik.
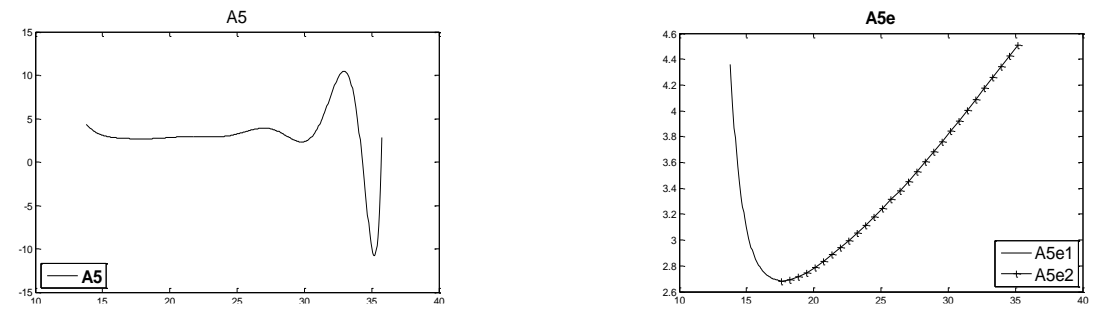

Gambar 8. Fungsi $f_{A 5}(x)$ dan $f_{A 5[e]}(x)$

Pada bagian A6 ada dua tipe data, sehingga terbentuk dua susunan fungsi dengan grafik.
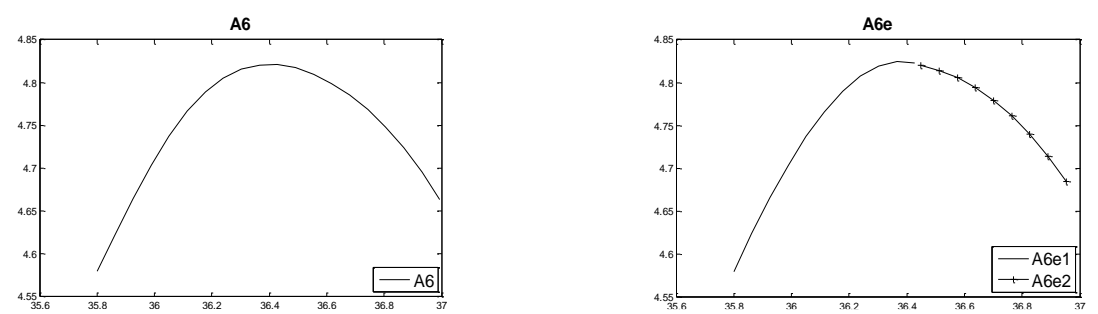

Gambar 9. Fungsi $f_{A 6}(x)$ dan $f_{A 6[e]}(x)$

Dari semua grafik yang dihasilkan di tiap bagian vas kayu A akan disusun menjadi satu sehingga menjadi grafik dari vas kayu A. Tetapi pada bagian yang memiliki lebih dari satu fungsi perlu dilakukan analisis pengamatan terlebih dahulu untuk mendapatkan grafik dari fungsi yang lebih mendekati bentuk vas kayu A pada bagian tersebut. 
- Pada bagian A2 karena kedua grafik serupa maka bias dipilih salah satunya.

- Pada bagianA3 grafik $f_{A 3}(x)$ lebih mendekati bagian A3.

- Pada A5 grafik dari $f_{A 5[e]}(x)$ lebih mendekati bagian A.

- Pada A6 grafik dari $f_{A 6}(x)$ lebih mendekati daerah A6.

Sehingga dari analisis pengamatan di atas didapatkan susunan fungsi dan grafik dari vas kayu A adalah sebagai berikut.

$$
f_{A}(x)= \begin{cases}f_{A 1}(x), & 0 \leq x \leq 2 \\ f_{A 2[e]}(x), & 2 \leq x \leq 3.05 \\ f_{A 3}(x), & 3.05 \leq x \leq 12.9 \\ f_{A 4}(x), & 12.9 \leq x \leq 13.78 \\ f_{A 5[e]}(x), & 13.78 \leq x \leq 35.8 \\ f_{A 6}(x), & 35.8 \leq x \leq 37\end{cases}
$$

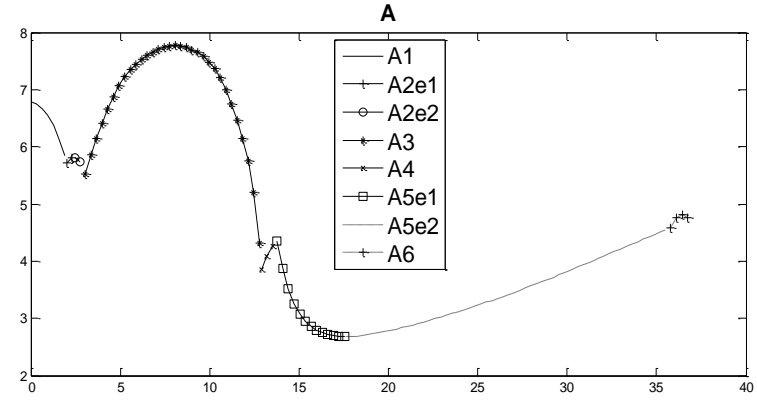

Gambar 10. Fungsi $f_{A}(x)$

Berikutnya akan didapatkan fungsi dari vas kayu B dari data pada tabel 2. Pada bagian B1 ada dua tipe data, sehingga terbentuk dua susunan fungsi dengan grafik.
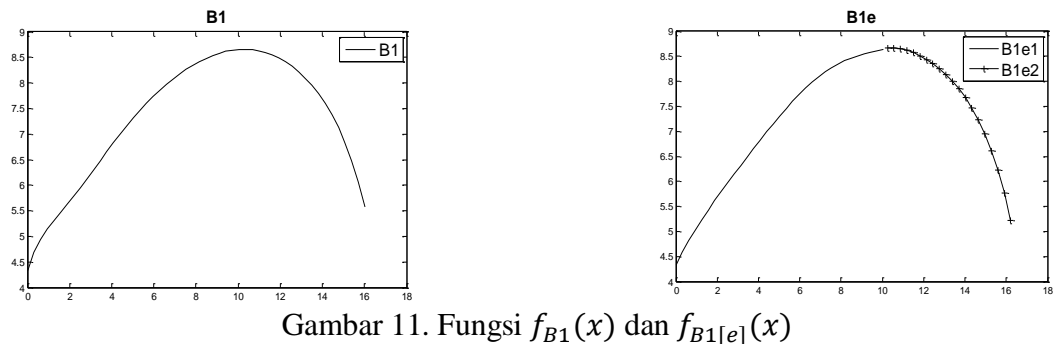

Pada bagian B2 ada tiga tipe data yaitu data dari semua titik di bidang B2, data yang dibatasi oleh titik ekstrem dan data yang dibatasi oleh titik belok. Dari tiga data tersebut didapatkan tiga susunan fungsi dengan grafik. 

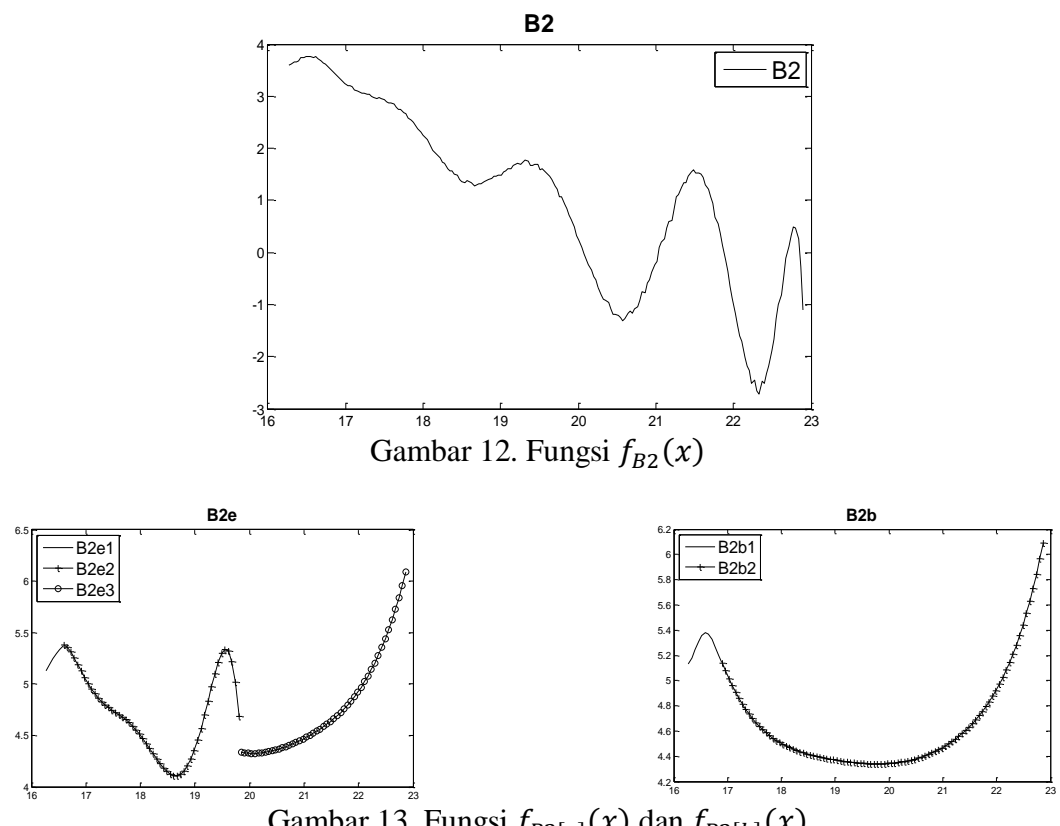

Gambar 13. Fungsi $f_{B 2[e]}(x)$ dan $f_{B 2[b]}(x)$

Bagian A4 hanya memiliki satu fungsi dengan grafik.

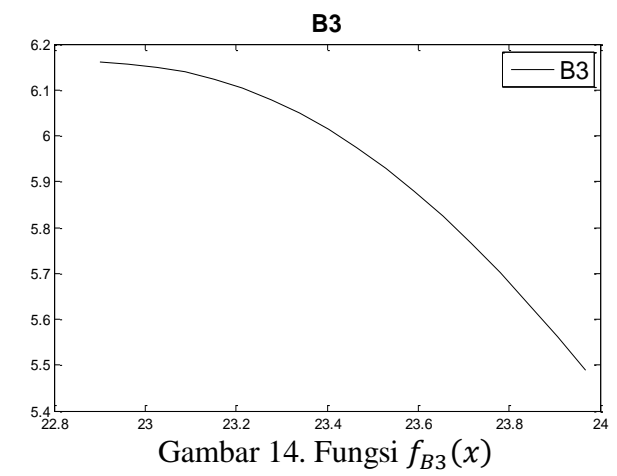

Dari semua grafik yang dihasilkan di tiap bagian vas kayu B akan disusun menjadi satu sehingga menjadi grafik dari vas kayu B. seperti pada vas kayu A, tiap bagian yang memiliki lebih dari satu susunan fungsi dilakukan analisis pengamatan terlebih dahulu untuk mendapatkan grafik dari fungsi yang lebih mendekati bentuk vas kayu B pada bagian tersebut.

- Pada bagian B1 grafik dari kedua fungsi tersebut sama-sama memiliki error yang sedikit di tempat yang berbeda, sehingga fungsi daerah B1 bisa salah satunya.

- Grafik dari $f_{B 2[b]}(x)$ lebih mendekati daerah B2.

Sehingga dari analisis pengamatan di atas didapatkan susunan fungsi dan grafik dari vas kayu B adalah sebagai berikut. 


$$
\begin{aligned}
& f_{B}(x)= \\
& \begin{cases}f_{B 1[e]}(x), & 0 \leq x \leq 16.27 \\
f_{B 2[b]}(x), & 16.27 \leq x \leq 22.9 \\
f_{B 3}(x), & 22.9 \leq x \leq 24\end{cases}
\end{aligned}
$$

Grafik dari $f_{B}(x)$ adalah sebagai berikut.

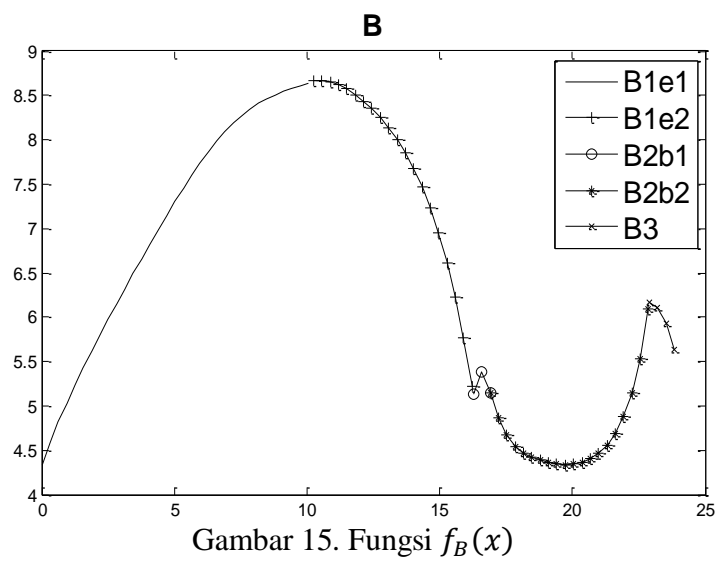

\section{Kesimpulan}

Dalam pembahasan di atas terlihat bahwa dari data yang sama dapat terbentuk fungsi dengan grafik yang sangat berbeda, dan dari satu tipe pembagian batas pada data belum tentu dapat menghasilkan fungsi dengan grafik yang mendekati benda putar yang diteliti. Sehingga untuk mendapatkan grafik fungsi yang mendekati atau sama dengan benda putar yang diteliti perlu dilakukan pengujian terhadap ketiga tipe data terlebih dahulu.

\section{Saran}

Peneliti menyarankan untuk menuliskan fungsi dalam bentuk rasional, hal ini disebabkan oleh peulisan dalam bentuk desimal dapat menghasilkan titik yang sangat jauh berbeda dari titik pada data yang diketahui.

\section{Referensi}

[1] Sukirman, 2006. "Logika Dan Himpunan”. Yogyakarta: Hangar Kreator

[2] Anton, Howard. 2000. "Dasar-dasar Aljabar Linear edisi 7 jilid 1" alih bahasa Ir. Hari Suminto. Batam Centre: Interaksa.

[3] Ruminta. 2009. "Matrik Persamaan Linear dan Pemrograman Linear". Bandung: Rekayasa Sains 